\title{
Sensitivity in the law of nuisance: should people in glass houses expect voyeurs? Fearn v Tate Gallery
}

Article

Accepted Version

Hilson, C. (2019) Sensitivity in the law of nuisance: should people in glass houses expect voyeurs? Fearn v Tate Gallery. Environmental Law Review, 21 (2). pp. 136-139. ISSN 14614529 doi: https://doi.org/10.1177/1461452919843663

Available at https://centaur.reading.ac.uk/82851/

It is advisable to refer to the publisher's version if you intend to cite from the work. See Guidance on citing.

To link to this article DOI: http://dx.doi.org/10.1177/1461452919843663

Publisher: SAGE Publications

All outputs in CentAUR are protected by Intellectual Property Rights law, including copyright law. Copyright and IPR is retained by the creators or other copyright holders. Terms and conditions for use of this material are defined in the End User Agreement.

www.reading.ac.uk/centaur

\section{CentAUR}


Central Archive at the University of Reading

Reading's research outputs online 


\section{Sensitivity in the Law of Nuisance: Should People in Glass Houses Expect Voyeurs? Fearn v Tate Gallery [2019] EWHC 246 (Ch)}

Chris Hilson

School of Law, University of Reading, UK, c.j.hilson@reading.ac.uk

ORCID iD: http://orcid.org/0000-0003-4114-6471

\section{Abstract}

The case Fearn v Tate Gallery involved claims brought by luxury London flat owners for breach of privacy in relation to the Tate Modern's nearby viewing platform. One of the key issues in the case, heard by Mann J in the High Court, was whether the floor-to-ceiling glass windows of the flats through which members of the public on the viewing platform could easily gaze - meant the residents were unduly sensitive users of the land for the purposes of the tort of nuisance. This case note considers this question along with the principle in nuisance that it is normally no defence to say that the claimant came to the nuisance. Both sensitivity and the coming to the nuisance (non-) defence are important elements of nuisance as an environmental tort and hence the case is worthy of note for environmental lawyers.

Keywords: Nuisance, privacy, coming to the nuisance, sensitivity

In Fearn v Tate Gallery, ${ }^{1}$ a number of residents of a newly constructed apartment block, NEO Bankside, sued the Tate Gallery in nuisance and under the Human Rights Act 1998 for breach of privacy as a result of intrusive viewing from the Tate Modern extension's public viewing gallery. In essence, due to this viewing platform opposite the flats, the flipside of their wonderful views through the floor-to-ceiling glass windows was that they had the feeling of living in a goldfish bowl. In a peculiar mirroring, reading the judgment is itself rather like peering into the flats and their owners' lives. The case attracted a significant amount of media and public attention: ${ }^{2}$ it's one where the facts naturally invite one to have an opinion and to take sides; it's also a case very much of our times, with the owners of multi-million pound flats garnering little sympathy from many millennial commentators who cannot afford their own homes. That the judge did not find for the flat owners arguably demonstrates a sensitivity to the political zeitgeist. ${ }^{3}$

On the nuisance claim - the focus of this Note - Mann J first established that nuisance as a tort was capable in principle of protecting privacy in the home. However, he ruled that there was no

\footnotetext{
${ }^{1}$ [2019] EWHC 246 (Ch).

${ }^{2}$ See e.g. Mark Brown, 'Tate Modern wins privacy case brought by owners of $£ 4 \mathrm{~m}$ flats', The Guardian, 12 February 2019, available at https://www.theguardian.com/artanddesign/2019/feb/12/tate-modern-winsprivacy-case-brought-by-owners-of-4m-flats; and Lucy Watson, 'UK property: throwing stones at people in London's glass houses' Financial Times, 15 February 2019, available at https://www.ft.com/content/dffc6c7a3053-11e9-8744-e7016697f225 (and the online comments by members of the public beneath the newspaper articles).

${ }^{3}$ Watson (n 2).
} 
actionable nuisance made out in this case because the flat owners, with their extensive glass windows, were unduly sensitive users of the land. The idea of 'reasonable user' in nuisance is to achieve a balance between competing land users: it is not possible to claim that another's land use (the viewing gallery here) is unreasonable if a non-sensitive neighbour would not have been troubled by it; and according to the judge, flats with 'normal' windows would not have attracted the same problem. There are, however, three objections that can be made to Mann J's ruling.

First, there are issues with his dismissal of the recent foreseeability turn in the sensitivity case law. The fact that this point had not been the subject of proper debate and argument before him and was considered only in a postscript, means that this can hardly be considered the judge's fault. It is, nevertheless, an important point to consider. In Network Rail v Morris, ${ }^{4}$ the claimant sued the defendants in nuisance in relation to electromagnetic interference with the electronic equipment in his recording studio. The court, conscious of the fact that we live in a society where sensitive electronic equipment is now quite commonplace, held that asking whether the claimant was a sensitive user was the wrong question. Instead one should ask whether Network Rail should have foreseen, when they were doing their signalling work, that this might have an impact on the claimant's studio. Now one might well argue (as I would) that this foreseeability turn was wrong because after all nuisance is still, in the reasonable user sense, a strict liability tort (the SedleighDenfield ${ }^{5}$ type cases aside). In other words, unlike negligence, it is not meant to focus on the defendant's behaviour in isolation - it is, rather, about achieving a relational balance between landowners. In that respect, examining foreseeability on the part of the defendant in the context of reasonable user (as opposed to remoteness, where foreseeability clearly now applies ${ }^{6}$ ) does look too fault-based and non-relational. However, as things stand, Network Rail remains good law. It would, however, prove inconvenient for the court in Fearn. Whereas Network Rail were held not liable because they could not foresee that their activity would affect the claimant's land use, the Tate Gallery could of course foresee that a viewing platform would give rise to an interference with the flat owners' use and enjoyment of their properties. ${ }^{7}$

As a result, Mann J sought to rely on Lord Phillips' judgment in Network Rail, claiming that it had left space open for sensitivity arguments. In fact, if one examines Lord Phillips' reasoning, the only plausible argument along these lines is that he confines foreseeability as a requirement to electronic interferences. In that type of case, foreseeability would it seems be the guiding principle; in other types, however (like here), the sensitivity principle could live on. There are, however, two problems with such a route. To begin with, the distinction seems questionable. On what basis should technological sensitivity be treated differently from other types? While it's true that sensitive electronic equipment is more commonplace today, the same is true of full length glazing: people today generally like more light in their homes. Next, the distinction leads to a divided principle rather than coherence: instead of one general principle governing sensitivity, separating out electronic equipment leaves us with two strands.

The second objection to Mann J's nuisance ruling is that it does not fully grasp the implications of the coming to the nuisance (non-)defence. As the judge observed, the NEO Bankside flats and the

\footnotetext{
${ }^{4}$ [2004] EWCA Civ 172.

5 [1940] AC 880.

${ }^{6}$ Post-Cambridge Water v Eastern Counties Leather [1994] 2 AC 264.

${ }^{7}$ As Mann J observes: "At one level foreseeability in the present case is obvious" [230].
} 
Tate extension were developed at roughly the same time and with cooperation between the developers. On the one hand he thought it would be strange, given that the developer of the flats was aware of the viewing gallery (though perhaps not its full impact) and in a sense consented to it, for subsequent owners of the flats to be able to complain about the nuisance. On the other hand, he acknowledged that it is no defence to say that the claimant came to the nuisance. Nevertheless, in the end he did not base his decision on this point because, again, it had not been fully argued before him and he had not heard evidence about the developer's knowledge.

This is unfortunate, as the coming to the nuisance principle is instructive here. First, there are dicta in Coventry $v$ Lawrence ${ }^{8}$ that might support Mann J's decision in favour of the defendants. In that case, Lord Neuberger held that the coming to the nuisance defence must fail "where the claimant in nuisance uses her property for essentially the same purpose as that for which it has been used by her predecessors since before the alleged nuisance started". ${ }^{9}$ However, he states that there is much more room for argument where a claimant builds on or changes the use of her property after the defendant has started the activity causing the alleged nuisance.

In Fearn, the flats had been built with 'winter gardens' intended as quasi-balconies - single glazed and designed, without heating, for occasional use. However, in due course, the design was changed and the developers put in under-floor heating. Part of the problem, according to the judge, was that the residents were then using the winter gardens, with their floor-to-ceiling windows, as full time living accommodation. Had the spaces stayed as balconies, there would have been less activity on them to draw the eye from those on the viewing gallery; and in any event one expects less privacy on a balcony in the first place. True, those at Tate Modern could also see through the double-glazed doors leading off the winter gardens; however, while the privacy of the living accommodation would therefore still have been compromised, their overall usage would, according to the judge, have been a less sensitive one. Based on Lord Neuberger's dicta in Coventry in Lawrence, one might argue that the developers and residents had changed the original use via building work to turn the balconies into living accommodation and therefore that the defence of coming to the nuisance ought, exceptionally, to apply here.

However, a counter argument can be made. One of the underlying policy arguments for the principle that coming to the nuisance is no defence, is that it prevents an existing use of land from being ossified: ${ }^{10}$ if an existing landowner such as the cricket club in Miller $v$ Jackson ${ }^{11}$ can raise a defence to any nuisance claim by incoming developments that they have come to the nuisance, then the character of the area might never change. How is this relevant to Fearn? If, as the judge says, the claimants (via the developers) can be said to have consented to the nuisance, then that is essentially the same as the coming to the nuisance defence being allowed. However, if allowed, then the Tate Modern viewing gallery effectively ossifies building design around it: no one with modern, desirable, floor-to-ceiling windows can move in nearby without suffering an invasion of privacy because they will be regarded as having come to the nuisance with their undue sensitivity. It would be akin to the

\footnotetext{
${ }^{8}$ [2014] UKSC 13.

9 [51].

$10 \mathrm{~J}$ Steele, Tort Law: Text, Cases and Materials, $4^{\text {th }}$ edn, OUP 2017, p.645.

${ }^{11}$ [1977] QB 966.
} 
cricket club in Miller being able to resist new development next door on the basis that houses with low fences were sensitive and somehow inviting stray cricket balls to come their way.

Finally, there is a slippery slope argument. In his ruling on sensitivity, Mann J states that the claimants would not have suffered the same level of intrusion had their flats had normal windows. Though converting the existing glazing to that sort would obviously be impractical, the judge was of the view that the residents could adopt lesser measures such as solar blinds, privacy film, net curtains or tall plants in order to mitigate the extent of intrusion and hence nuisance. He acknowledged that it is "unusual for a nuisance claim to be met by the defendant saying that the claimant could take remedial steps to avoid the consequences of the act". ${ }^{12}$ Hence, the "victim of excessive dust would not be expected to put up additional sealing of doors and windows; the victim of excessive noise would not be expected to buy earplugs." ${ }^{13}$ However this was, in his view, an unusual case: privacy is different because some have stronger feelings on it than others - as exemplified by varying attitudes to net curtains. That meant it was "acceptable to expect those wishing to enhance it to protect their own interests." ${ }^{14}$ In the end, nuisance is a matter of reasonableness of competing land users and he felt it would not be unreasonable to expect the flat owners to take some of the mitigating measures above.

The problem with Mann J's approach lies in the assumption that privacy is different and will remain distinguishable in future cases. Is privacy really different? After all, attitudes to noise differ, which is why some people don't mind living near a busy road or an airport, while others do. Why not require mitigation in noise cases? Earplugs, the example given by Mann J, lie at the more obviously cheekily unreasonable end of the spectrum of what one might expect of a claimant in mitigation terms. However, there is surely a danger that, in a future case, a party will be tempted to argue that someone near a noisy land user with (increasingly unusual) ordinary single glazing is unduly sensitive to noise and they should therefore take mitigating measures by fitting double glazing. The noise is, after all, only unreasonable because of the undue sensitivity caused by their glazing and it may not be unreasonable to expect them to upgrade it. Few courts would accept either the earplugs or double glazing argument however. That is where the slippery slope lies: it seems very hard to justify containing Mann J's argument to privacy-type nuisances arising from being intrusively overlooked. And applying it outside of that context leads to claims that look unacceptable.

While it's not an obvious environmental law case, Fearn has important implications for the subject. Nuisance remains one of the classic environmental torts and any decision that tinkers with some of core principles of the tort such as sensitivity and coming to the nuisance could impact future cases. In many respects while an easy dispute to have an opinion on, Fearn is, legally-speaking, a hard case; and as we know, hard cases often make bad law.

\footnotetext{
12 [215].

13 ibid.

${ }^{14}$ ibid.
} 